\title{
THEME-RHEME ANALYSIS AND THEMATIC PROGRESSION IN JOKO WIDODO'S SPEECH
}

\author{
Like Raskova Octaberlina ${ }^{1, *}$, Afif Ikhwanul Muslimin ${ }^{2}$ \\ ${ }^{1}$ English Education Department, Faculty of Education and Teacher Traning, Universitas Islam Negeri \\ Maulana Malik Ibrahim Malang, Malang 65144, Indonesia \\ ${ }^{2}$ English Education Department, Faculty of Education and Teacher Training, Universitas Islam Negeri \\ Mataram, Mataram 83125, Indonesia
}

\section{ARTICLE INFO}

Keywords:

Cohesion

Speech

Theme-Rheme

Thematic progression

Article History:

Received: $22 / 10 / 2020$

Accepted: 29/11/2020

Available Online:

$30 / 11 / 2020$

\begin{abstract}
A B S T RA C T
Indonesia president, Mr. Joko Widodo, delivered a speech concerning some decisions related to social support and people's massive movements to stop the COVID-19 in Indonesia. Some unique functional grammar, namely theme-rheme and thematic progression, are found in his speech. The research focuses on analyzing the theme-rheme and the thematic progression (TP) types in Joko Widodo's speech both in the source language (SL) or Bahasa Indonesia and target language (TL) or English translation. It made a comparison to depict the differences and similarities between them. This study was a descriptive qualitative research method by taking the speech texts and their translation. The research results showed that the most frequently used theme in both SL and TL speech texts was the topical theme (66\%). The second was the textual theme, and the least used was the interpersonal theme. Both SL and TL speech texts employed all thematic progression that shows the texts have been developed cohesively. However, the theme derived thematic progression becomes the most frequent TP as the speaker and translator used a single theme to develop another related theme in the next clause. This type of TP stated the different dominant types of TP used by other presidents' speech.
\end{abstract}

2442-305X / C 2020 The Authors, this is open access article under the (CC-BY-NC) license (https://creativecommons.org/licenses/by-nc/4.0/), DOI: 10.19105/ojbs.v14i2.3900

\footnotetext{
* Corresponding Author:

Email address: like@uin-malang.ac.id (L. R. Octaberlina)
}

\section{A. Introduction}

English as language which becomes mean of communication plays a pivotal role in human life for interaction in the society. English bounds people from different environments, social status, tribes, and countries. It would be challenging if people should transfer information without language as well as to convey it. Language is the resource for making meaning. Halliday mentions that meaning has been built through a system in the language. ${ }^{1}$ This statement

1 M. A. K. Halliday and Christian M.I.M. Matthiessen, Introduction to Functional Grammar, 4th ed. (London: Routledge, 2014), 3. 
emphasizes the idea of that every single language that is produced by someone will also carry meaning. So, to be able to take advantage of English as language to transfer the meaning, people must learn English as science.

English linguistics as science shows that English has some aspects including grammar, vocabulary, sound systems, register, context, and others. According to Zhang, grammar is the complex aspect that many English learners have failed to use correctly. ${ }^{2}$ Although it is considered as difficult, some still believe that acquiring English does not need to be good in grammar. Consequently, the English users do not pay attention to the precise use of grammar, resulting in mistakes in their language productions in speaking or writing. Moreover, the information that the users want to share will not successfully be caught by the audiences. Furthermore, understanding functional grammar (FG) as it sees language as a resource of meaning is believed to help English learners make effective communication. ${ }^{3}$

In the past decade or so applied linguists, especially in east asia ( $\mathrm{Liu},{ }^{4}$ Wang, ${ }^{5}$ Yang, ${ }^{6}$ Ping, ${ }^{7}$ and Liu $^{8}$ ) promoted

2 Jianyun Zhang, "Necessity of Grammar Teaching," International Education Studies 2, no. 2 (2009): 184-97, https://doi.org/10.5539/ies.v2n2p184.

${ }^{3}$ Linda Gerot and Peter Wignell, Making Sense of Functional Grammar (Cammeray: Antipodean Educational Enterprises, 1995), 208.

4 S. Liu, "Thematic Progression: Analysis and Interpretation," US-China Foreign Lang. 2, no. 12 (2004): 68-71.

${ }^{5}$ Lixia Wang, "Theme and Rheme in the Thematic Organization of Text: Implications for Teaching Academic Writing," The Asian EFL Journal Quarterly 9, no. 1 (2007): 164-76, the idea that teaching Functional Grammar involving rheme and theme, and also thematic progression will improve the coherence of student's writing. Hence, studying about theme and rheme and also thematic progression are really helpful for the teachers to employ this topic in the classroom.

Theme (something precedes) and rheme (something that continues are two important points in the systemic-FG (Functional Grammar). The definition of theme based on Halliday and Matthiessen's idea is "The Theme is the element that serves as the point of departure of the message; it is that which locates and orients the clause within its context." It means that theme is situated at the beginning of the clause or sentence. The beginning part in a clause is usually where someone connect the clause with something that has been explain before. Theme in a clause always contains understandable or referential information stated somewhere in text or is normally known through context. The understanding of the nominal group or subject in a clause which brings the main

http://www.asian-efl-

journal.com/March_2007_EBook.pdf.

${ }^{6}$ Xueqian Yang, "Thematic Progression Analysis in Teaching Explanation Writing," English Language Teaching 1, no. 1 (2008): 29-33, https://doi.org/10.5539/elt.v1n1p29.

7 Alvin Leong Ping, "Developing the Message: Thematic Progression and Student Writing," The Journal of Asia TEFL 4, no. 3 (2007): 93-127.

8 Quing-Feng Liu, "Thematic Selection and Progression in EFL Writing," US-China Foreign Lang. 7, no. 7 (2009): 25-29.

9 Halliday and Matthiessen, Introduction to Functional Grammar, 89. 
information is important. ${ }^{10}$ The theme has divided into two parts, they are: simple theme that is commonly called as topical theme and multiple themes which consist of textual theme and interpersonal theme.

Halliday \& Matthiessen states that topical theme appears when the first constituent of a clause is process, circumstance, or participant. ${ }^{11}$ The first constituent form can be in the form of a nominal group or a prepositional phrase. It means that there are many categories of topical theme based on the first constituent, such as: participant, process, circumstantial of matter, circumstantial of time, circumstantial of manner, circumstantial of place, circumstantial of cause, circumstantial of accompaniment, and circumstantial of role.

The textual theme according to Halliday \& Matthiessen can be noted as the existence of conjunctions (for, and, nor, but, or, yet, so), continuative (well, oh, let, no, yes), and conjunctive adjunct (while, then, otherwise, though, for example). ${ }^{12}$ Giroux states that conjunctive adjuncts may be situated everywhere in sentences, while conjunction is usually placed at the beginning. The definition show that conjunctive functions as relation maker and tool to make logical idea between messages. ${ }^{13}$

${ }^{10}$ Gerot and Wignell, Making Sense of Functional Grammar, 7.

11 Halliday and Matthiessen, Introduction to Functional Grammar, 105.

12 Halliday and Matthiessen, 105.

13 Henry A. Giroux, Pedagogy and the Politics of Hope: Theory, Culture, and Schooling (Oxford: Westview Press, 1997), 150.
One of the multiple themes is the interpersonal theme. This theme is characterized by the ability to make relations among participants in clause or show the author's attitude in text. ${ }^{14}$ Halliday \& Matthiessen mention that interpersonal theme can be in the form of a finite in an interrogative clause that starts the mood adjuncts (in my opinion, surprisingly, unfortunately), vocatives (someone's name used to address), and subject. $^{15}$

Meanwhile, the rheme is understood as part in the clause that develops the information of the theme. The rheme consists of new or unfamiliar information that has not yet been stated in the previous clause or sentence. The simple way to notice it only by understanding that everything comes after the theme is the rheme. Eggins explains that once someone has identified the theme in a sentence or clause, he/she has also caught the rheme that is only 'everything else'. $^{16}$

The study of theme and rheme in the English language relies on the study from the systemic functional linguistics (SFL) which analyzes English language from the perspective of function. ${ }^{17}$ Speech as one of the language production activities that make language function also

\footnotetext{
14 Brian Paltridge, Discourse Analysis: An Introduction (New York: Continuum, 2006), 145.

15 Halliday and Matthiessen, Introduction to Functional Grammar, 107.

16 Suzanne Eggins, An Introduction to Systemic Functional Linguistics, 2nd ed. (New York: Continuum International Publishing Group, 2004), 300.

17 Halliday and Matthiessen, Introduction to Functional Grammar, 88.
} 
employs theme and rheme in their script which can be analyzed scientifically. Furthermore, the analysis may show the progression of theme and rheme inside the script may show the cohesion of information that influences the audience's understanding.

Indonesia president, Mr. Joko Widodo, in relation with the efforts to stop the COVID-19 virus in Indonesia, has actively lead Indonesia society to make one movement, to have one idea, and to get similar target through his speeches. Recently, as the pandemic impact has gotten massive reaching 7.351 people in

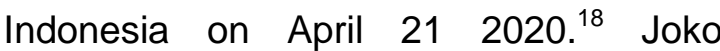
Widodo made some decisions related to social support and people's massive movements. Lately, the speech was translated into English, which made the researcher's interest to analyze based on its theme-rheme and thematic progression.

Past studies have so far looked at the written text, mostly students' written text. Hawes analyzed the use of thematic progression in essays by the students on a course leading to MA studies in journalism, media, and communications with that in two leading British newspapers. ${ }^{19}$ Ridha also studied different types of theme problems in English

18 C. N. N. Indonesia, "Update Corona April 21: 7.135 Positif, 616 Meninggal," nasional, accessed November 21 ,

2020 ,

https://www.cnnindonesia.com/nasional/202004211 20855-20-495594/update-corona-21-april-7135positif-616-meninggal.

19 Thomas Hawes, "Thematic Progression in the Writing of Students and Professionals," Ampersand 2 (2015): 93-100, students' written texts in Basra University, College of Education for Humanities, Department of English. ${ }^{20}$ Sri Yunita's research also investigated the theme and thematic progression patterns in students' recount text in a state vocational school in Bandung. ${ }^{21}$ However, other options can be studied, such as by analyzing themerheme and thematic progression in the spoken text in the form of speech. Furthermore, the thematic progression in spoken text studies is very limited.

This study is intend to fill that gap. By targeting the speech by Indonesian President, Mr. Joko Widodo, regarding the efforts to stop COVID-19 that have been officially transripted into Bahasa Indonesia and translated into English. This study aims to analyze the theme-rheme and thematic progression of in president's speech.

\section{B. Method}

This study used the descriptive qualitative method. It is relevant and appropriate since the study described the worldview in a text through textual analyses using theme-rheme theory and thematic progression theory. Regarding the object of the research which is in form of text, this study applied content analysis to analyze the theme which is most frequently used as well as their

\footnotetext{
${ }^{20}$ Nada Salih Abdul Ridha, "Theme and Rheme: Types and Problems in EFL University Students' Written Texts," Journal of Basrah Researches (Humanities Series) 39, no. 1 (2014): 94-114.

${ }^{21}$ Sri Yunita, "Theme and Thematic Progression in Students' Recount Texts," Indonesian Journal of Applied Linguistics 7, no. 3 (2018): 524-530, https://doi.org/10.17509/ijal.v7i3.9797.
} 
differences in the source language (SL) and target language (TL) text.

The researcher chose the scripts in English and Bahasa Indonesia as the main data. The data of the research were taken from complete speech of Joko Widodo (president of Indonesia Republic) that was delivered on April 21, 2020 which is accessed from https://setkab.go.id for the SL format. ${ }^{22}$ The translated version of speech ( $T L$ ) was taken from the same website https://setkab.go.id but with the English translation. ${ }^{23}$ The translation was made by Syarifah Aisyah and was Reviewed by M. Ersan Pamungkas.

In analyzing the data, the researcher used the theme-rheme theory which was introduced by Halliday, which was developed by Gerot and Wignell. ${ }^{24}$ There are some theories on the types of thematic progressions (TP): 1) Eggins proposes two thematic progressions, they

\footnotetext{
22 Humas Sekretariat Kabinet Republik Indonesia, "Rapat Terbatas melalui Video Conference Mengenai Lanjutan Pembahasan Antisipasi Mudik, 21 April 2020, di Istana Merdeka, Provinsi DKI Jakarta," April 21, 2020, https://setkab.go.id/rapatterbatas-melalui-video-conference-mengenailanjutan-pembahasan-antisipasi-mudik-21-april2020-di-istana-merdeka-provinsi-dki-jakarta/.

${ }^{23}$ Office of Assistant to Deputy Cabinet Secretary for State Documents \& Translation, "Introductory Remarks of President of the Republic of Indonesia During the Limited Cabinet Meeting Through Video Conference on the Additional Discussion for the Anticipation of Anual Exodus," Sekretariat Kabinet Republik Indonesia, April 22, 2020, https://setkab.go.id/en/introductory-remarks-ofpresident-of-the-republic-of-indonesia-during-thelimited-cabinet-meeting-through-video-conferenceon-the-additional-discussion-for-the-anticipation-ofanual-exodus-tuesday/.

${ }^{24}$ Gerot and Wignell, Making Sense of Functional Grammar, 103.
}

are multiple and zig-zag themes; ${ }^{25}$ 2) Paltridge explains that there are three thematic progressions. ${ }^{26}$ They are linear theme, split rheme, and constant theme; and 3) Danes postulated four thematic progression types. Three main types involve simple linier TP, constant TP, and theme derived TP. ${ }^{27}$ Additional types namely split rheme TP is often mentioned as type $4 .^{28}$ Then, this research chose the theory of Danes as the basis of the thematic progression analysis.

To get the main result of this research, the researcher conducted several steps in analyzing the data. The first step was breaking down the speech into clauses, then analyzing the clauses using theme-rheme. After analyzing the theme rheme of the clauses in the speech, the analysis of thematic progression was carried out to these clauses. The result of the analysis was used to find out the worldview in the texts and find out the theme that is most frequently used in the SL and TL text.

\footnotetext{
${ }^{25}$ Eggins, An Introduction to Systemic Functional Linguistics, 324-25.

26 Paltridge, Discourse Analysis: An Introduction, 148-50.

27 Frantisek Daneš, "Functional Sentence Perspective and the Organization of the Text," in On Subject and Theme, by Frantisek Daneš (Amsterdam: John Benjamins Publishing, 1974), 108-24.

28 Another researcher stated that Danes only postulated three main types. However, the Split Rheme is often quoted as "Type 4", although it is in fact a combination of Types 1 and 2. See Angela Downing, "Thematic Progression as A Functional Resource in Analyzing the Text," in Os Estudios Ingleses No Contexto Das Novas Tendencias, by M.T. Caneda and J. Pérez (Vigo: Universidade de Vigo, 2001), 23-42.
} 


\section{Results}

The present research investigated the theme and rheme that existed in the speech delivered by Joko Widodo due to reducing the spreading of the COVID-19 pandemic on April 21, 2020. Then, after identifying the clauses in the speech texts in English as a target language (TL) and Indonesia as a source language (SL), the numbers of themes are presented as follows.

Table 1.

Themes in Source Language (SL) Speech Text

\begin{tabular}{|c|c|c|c|c|}
\hline No & Theme Category & & Freq. & Percentage (\%) \\
\hline \multirow[t]{9}{*}{1.} & Topical Theme & Circumstantial of time & 1 & $3 \%$ \\
\hline & & Circumstantial of place & 2 & $6 \%$ \\
\hline & & Circumstantial of manner & - & - \\
\hline & & Circumstantial of cause & - & - \\
\hline & & Circumstantial of accompaniment & - & - \\
\hline & & Circumstantial of matter & 12 & $38 \%$ \\
\hline & & Circumstantial of role & - & - \\
\hline & & Participants & 5 & $16 \%$ \\
\hline & & Process & 1 & $3 \%$ \\
\hline \multirow[t]{3}{*}{2.} & Textual Theme & Continuity & - & - \\
\hline & & Conjunctive Adjunct & 8 & $25 \%$ \\
\hline & & Conjunction & 1 & $3 \%$ \\
\hline \multirow[t]{2}{*}{3.} & Interpersonal Theme & Modal Adjunct & 2 & $6 \%$ \\
\hline & & Vocative & - & - \\
\hline Total & & & 32 & $100 \%$ \\
\hline
\end{tabular}

Table 1 shows that the most frequently used theme in SL speech text is a topical theme that amounts to $66 \%$. The second is the textual theme with $28 \%$ use. The last is the interpersonal theme with only $6 \%$. The most dominant type of topical theme that appears in the SL speech text was circumstantial of matter with a percentage of $38 \%$.

The sample analyses of the themes are as follows.

\section{Circumstantial of Matter as Topical} Theme

\begin{tabular}{|c|c|}
\hline Bansos & $\begin{array}{c}\text { Sudah mulai dilaksanakan } \\
\text { kemarin }\end{array}$ \\
\hline TpT & $\mathrm{R}$ \\
\hline
\end{tabular}

The word "Bansos" or 'social support/aid' in English acts as a matter that is discussed in the topical theme. "Bansos" (social aid) precedes the rheme "Sudah mulai dilaksanakan kemarin" (has been started yesterday) as the rest of the theme. 


\section{Participant as Topical Theme}

\begin{tabular}{|c|c|}
\hline Saya & ingin langsung saja \\
\hline TpT & $\mathrm{R}$ \\
\hline
\end{tabular}

The word "saya" or 'l' in English acts as participant in topical theme. "Saya" (I) precedes the rheme "ingin langsung saja" (let me go straight to the point) as the rest of the theme.

\section{Conjunction as Textual Theme}

\begin{tabular}{|c|c|c|}
\hline jadi & $\begin{array}{c}\text { dari hasil kajian-kajian } \\
\text { yang ada di lapangan, } \\
\text { pendalaman yang ada di } \\
\text { lapangan, kemudian juga } \\
\text { dari hasil survey yang } \\
\text { dilakukan oleh } \\
\text { Kementerian }\end{array}$ & $\begin{array}{c}\text { disampaikan } \\
\text { bahwa .... }\end{array}$ \\
\hline
\end{tabular}

\begin{tabular}{|c|c|c|}
\hline & Perhubungan, & \\
\hline TxT & TpT & $\mathrm{R}$ \\
\hline
\end{tabular}

The word "jadi" or 'so' in English acts as a conjunctive adjunct that is discussed in textual theme. "Jadi" (so) precedes the topical theme rheme dari hasil kajian-kajian yang ada di lapangan, pendalaman yang ada di lapangan, kemudian juga dari hasil survey yang dilakukan oleh Kementerian Perhubungan (based on the results of the research on the ground, the deepened research on the ground, as well as the results of a survey conducted by Ministry of Transportation), and the rheme "disampaikan bahwa ..." (we found ...) as the rest of the theme.

Table 2.

Themes in Target Language (TL) Speech Text

\begin{tabular}{|c|c|c|c|c|}
\hline No & Theme Category & & Freq. & Percentage (\%) \\
\hline \multirow[t]{9}{*}{1.} & Topical / Ideational Theme & Circumstantial of time & - & - \\
\hline & & Circumstantial of place & 1 & $3 \%$ \\
\hline & & Circumstantial of manner & - & - \\
\hline & & Circumstantial of cause & - & - \\
\hline & & Circumstantial of accompaniment & 1 & $3 \%$ \\
\hline & & Circumstantial of matter & 9 & $28 \%$ \\
\hline & & Circumstantial of role & - & - \\
\hline & & Participants & 10 & $30 \%$ \\
\hline & & Process & 1 & $3 \%$ \\
\hline \multirow[t]{3}{*}{2.} & Textual Theme & Continuity & 1 & $3 \%$ \\
\hline & & Conjunctive Adjunct & 6 & $18 \%$ \\
\hline & & Conjunction & 4 & $12 \%$ \\
\hline \multirow[t]{2}{*}{3.} & Interpersonal Theme & Modal Adjunct & - & - \\
\hline & & Vocative & - & - \\
\hline Total & & & 33 & $100 \%$ \\
\hline
\end{tabular}


Table 2 describes the themes that appear in TL speech text. The result shows that the most frequently used theme in TL speech text is a topical theme that amounts $67 \%$. The second is textual theme with $33 \%$ use. On the other hand there is no interpersonal theme that is applied in the TL speech text. Then, the most dominant type of topical theme in the SL speech text was participants with a percentage of $30 \%$.

The sample analyses of the themes are as follows.

\section{Participant as Topical Theme}

\begin{tabular}{|c|c|}
\hline We & $\begin{array}{c}\text { have launched the distribution of } \\
\text { staple food to Greater Jakarta and the } \\
\text { Pre-employment Card program }\end{array}$ \\
\hline TpT & $\mathrm{R}$ \\
\hline
\end{tabular}

The word "We" acts as participant in topical theme. "We" precedes the rheme "have launched the distribution of staple food to Greater Jakarta and the Preemployment Card program" as the rest of the theme.

\section{Circumstantial of Matter as Topical Theme}

\begin{tabular}{|c|c|}
\hline Direct cash aid & $\begin{array}{c}\text { will be also carried out by } \\
\text { this week. }\end{array}$ \\
\hline TpT & $\mathrm{R}$ \\
\hline
\end{tabular}

The words "Direct cash aid" acts as matter that is discussed in topical theme. "Direct cash aid" precedes the rheme "will be also carried out by this week" as the rest of the theme.

\section{Conjunctive Adjunct as Textual Theme}

\begin{tabular}{|c|c|c|}
\hline Therefore, & I & $\begin{array}{c}\text { ask for any } \\
\text { preparations } \\
\text { regarding the } \\
\text { issue. }\end{array}$ \\
\hline TxT & TpT & R \\
\hline
\end{tabular}

The word "Therefore" acts as conjunctive adjunct that is discussed in textual theme. "Therefore" precedes the topical theme "I" and the rheme "ask for any preparations regarding the issue" as the rest of the theme.

The next finding was the thematic progression in English (TL) and Indonesia (SL) speech texts. First, the thematic progression of SL speech text is presented as follows:

\begin{tabular}{|c|c|}
\hline Selamat pagi, Salam sejahtera & bagi kita semuanya. \\
\hline T1 & $\mathbf{R 1}$ \\
\hline
\end{tabular}

\begin{tabular}{|c|c|c|}
\hline Saya & ingin langsung saja, & \\
\hline T2 & $\mathbf{R 2}$ & \\
\hline Jadi & $\begin{array}{c}\text { dari hasil kajian-kajian yang ada di lapangan, } \\
\text { pendalaman yang ada di lapangan, kemudian } \\
\text { juga dari hasil survei yang dilakukan oleh } \\
\text { Kementerian Perhubungan, }\end{array}$ & disampaikan... \\
\hline R2 > T3 & $\mathbf{R 3}$ & \\
\hline bahwa yang tidak & 68 persen, & \\
\hline
\end{tabular}

OKARA: Jurnal Bahasa dan Sastra, Vol. 14, No. 2, November 2020 


\begin{tabular}{|c|c|c|}
\hline mudik & & \\
\hline $\mathrm{T} 3>\mathrm{T} 4$ & R4 & \\
\hline $\begin{array}{l}\text { yang tetap masih } \\
\text { bersikeras mudik }\end{array}$ & 24 persen, & \\
\hline T3 > T5 & R5 & \\
\hline yang sudah mudik & 7 persen. & \\
\hline T3 > T6 & R6 & \\
\hline Artinya, & masih ada angka & $\begin{array}{l}\text { yang sangat besar, } \\
\text { yaitu } 24 \text { persen tadi. }\end{array}$ \\
\hline T3 > T7 & R7 & \\
\hline
\end{tabular}

\begin{tabular}{|c|c|}
\hline Kemudian yang kedua, & yang berkaitan dengan bansos. \\
\hline T8 & $\mathbf{R 8}$ \\
\hline
\end{tabular}

\begin{tabular}{|c|c|c|}
\hline Bansos & sudah mulai dilaksanakan kemarin, & \\
\cline { 1 - 2 } R8 > T9 & $\mathbf{R 9}$ & \\
\cline { 1 - 2 } $\begin{array}{c}\text { pembagian sembako } \\
\text { untuk Jabodetabek, }\end{array}$ & $\ldots$. & \\
\hline T9 > T10 & $\mathbf{R 0}$ & \multirow{2}{*}{ sudah berjalan. } \\
\hline Kemudian & Kartu prakerja & \\
\hline R8 > T11 & $\mathbf{R 1 1}$ & \\
\end{tabular}

\begin{tabular}{|c|c|c|}
\hline Minggu ini juga & bantuan sosial (bansos) tunai & juga sudah dikerjakan. \\
\hline & $\mathbf{R 8}>\mathbf{T 1 2}$ & $\mathbf{R 1 2}$ \\
\hline
\end{tabular}

\begin{tabular}{|c|c|c|c|}
\hline Dari sini lah & kemudian & saya. & ingin mengambil sebuah keputusan \\
\hline \multicolumn{3}{|c|}{ T3 > T13 } & $\mathbf{R 1 3}$ \\
\hline
\end{tabular}

\begin{tabular}{|c|c|c|c|}
\hline $\begin{array}{c}\text { Setelah larangan mudik bagi } \\
\text { ASN, TNI, Polri, dan pegawai } \\
\text { BUMN sudah kita lakukan } \\
\text { pada minggu yang lalu, }\end{array}$ & pada rapat hari ini & saya & $\begin{array}{c}\text { ingin menyampaikan } \\
\text { juga..... }\end{array}$ \\
\hline \multicolumn{2}{|c|}{$\mathbf{R 1 3}>$ T14 } & $\mathbf{R} 14$ \\
\hline Bahwa mudik semuanya & akan kita larang. & \\
\cline { 1 - 2 } T14 > T15 & $\mathbf{R 1 5}$ & \\
\hline
\end{tabular}

\begin{tabular}{|c|c|c|}
\hline Oleh sebab itu, & saya & minta persiapan-persiapan... \\
\hline \multicolumn{2}{|c|}{ R15 > T16 } & R16 \\
\hline \multicolumn{2}{|c|}{...yang } & berkaitan dengan.... \\
\hline
\end{tabular}




\begin{tabular}{|c|c|}
\hline R16 $>$ T17 & R17 \\
\hline ini & mulai disiapkan. \\
\hline T15 $>$ T18 & R18 \\
\hline
\end{tabular}

\begin{tabular}{|c|c|c|}
\hline Saya rasa & Itu & yang bisa saya sampaikan. \\
\hline \multicolumn{2}{|c|}{ T15 > T19 } & R19 \\
\hline
\end{tabular}

The more simple way to see the thematic progression of the source language (SL) speech text is presented in the following chart:

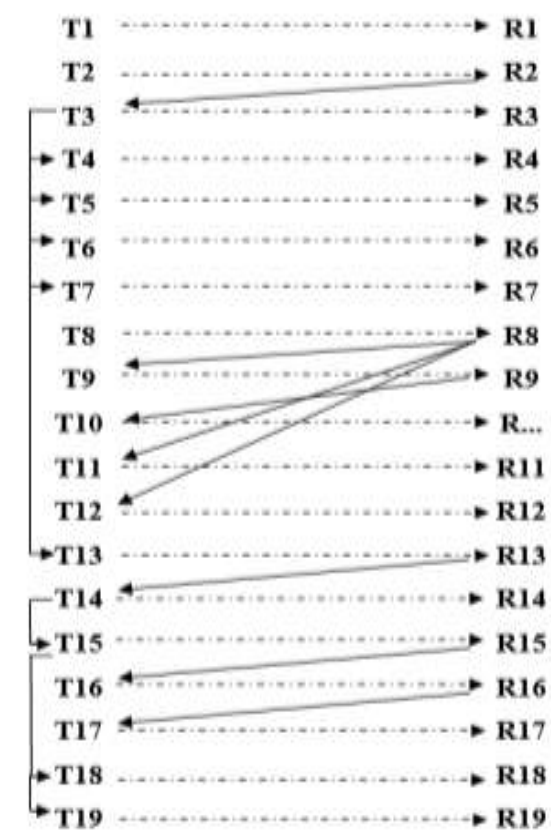

Fig 1. Thematic progression of SL speech text

Table 3.

Usage Frequency of Thematic Progression in SL Speech Text

\begin{tabular}{|c|c|c|c|c|c|}
\hline No & Type of TP & Freq & $\%$ & Position & Rank \\
\hline 1. & $\begin{array}{l}\text { Simple linear thematic } \\
\text { progression }\end{array}$ & 5 & $31 \%$ & $\begin{array}{l}\mathrm{R} 2>\mathrm{T} 3, \mathrm{R} 9>\mathrm{T} 10, \mathrm{R} 13>\mathrm{T} 14 \\
\mathrm{R} 15>\mathrm{T} 16, \mathrm{R} 16>\mathrm{T} 17\end{array}$ & 2 \\
\hline 2. & Constant thematic progression & 1 & $6 \%$ & $\mathrm{~T} 14>\mathrm{T} 15$ & 4 \\
\hline 3. & $\begin{array}{l}\text { Theme derived thematic } \\
\text { progression }\end{array}$ & 7 & $44 \%$ & $\begin{array}{l}\text { T3 > T4, T5, T6, T7, T13 } \\
\text { T15 > T18, T19 }\end{array}$ & 1 \\
\hline 4. & $\begin{array}{l}\text { Split rheme thematic } \\
\text { progression }\end{array}$ & 3 & $19 \%$ & $\mathrm{R} 8>\mathrm{T} 9, \mathrm{~T} 11, \mathrm{~T} 12$ & 3 \\
\hline
\end{tabular}

Based on the thematic progression analysis above, the Indonesia (SL) speech text employs all types of thematic progressions, including constant thematic progression, simple linear thematic progression, theme derived thematic progression and split rheme thematic progression. The detail of the usage frequency is described in table 3 below. 
The most frequently used of thematic progression in SL speech text is theme derived thematic progression as the main theme (T3) "dari hasil kajiankajian yang ada di lapangan, pendalaman yang ada di lapangan, kemudian juga dari hasil survei yang dilakukan oleh Kementerian Perhubungan" is used as basis to develop subthemes in T4 (yang tidak mudik), T5 (yang tetap masih bersikeras mudik), T6 (yang sudah mudik), T7 (Artinya, masih ada...), and T13 (dari sinilah, kemudian saya). Then, theme in sentence 15 (T15) Bahwa mudik semuanya... is used as the basis to make T18 (...ini..) and T19 (saya rasa, itu...).

Second, the thematic progression of TL speech text is presented as follows.

\begin{tabular}{|c|c|}
\hline Peace and prosperity & be upon us all. \\
\hline T1 & R1 \\
\hline
\end{tabular}

\begin{tabular}{|c|c|c|}
\hline Let & Me & go straight to the point. \\
\hline T2 & $\mathbf{R 2}$ \\
\hline
\end{tabular}

\begin{tabular}{|c|c|c|c|c|}
\hline So & \multicolumn{2}{|c|}{$\begin{array}{l}\text { based on the results of the research on the ground, } \\
\text { the deepened research on the ground, as well as the } \\
\text { results of a survey conducted by Ministry of } \\
\text { Transportation, }\end{array}$} & we & found... \\
\hline \multicolumn{4}{|c|}{$R 2>T 3$} & R3 \\
\hline \multicolumn{2}{|c|}{ that 68 percent of people } & \multicolumn{2}{|c|}{ will not participate in the annual exodus (mudik), } & \\
\hline \multicolumn{2}{|c|}{$\mathrm{T} 3>\mathrm{T} 4$} & \multicolumn{2}{|l|}{ R4 } & \\
\hline While & 24 percent & \multicolumn{2}{|l|}{ still insist on leaving, } & \\
\hline \multicolumn{2}{|c|}{$\mathrm{T} 3>\mathrm{T} 5$} & \multicolumn{2}{|l|}{ R5 } & \\
\hline And & 7 percent & \multicolumn{2}{|l|}{ have left. } & \\
\hline \multicolumn{2}{|c|}{ T3 $>$ T6 } & \multicolumn{2}{|l|}{ R6 } & \\
\hline
\end{tabular}

\begin{tabular}{|c|c|c|}
\hline It & Means & \\
\hline $\mathrm{T} 3>\mathrm{T} 7$ & R7 & \\
\hline That & We & $\begin{array}{c}\text { still have a very large } \\
\text { number, }\end{array}$ \\
\hline \multicolumn{2}{|c|}{$\mathrm{T} 3>\mathrm{T} 8$} & $\mathbf{R 8}$ \\
\hline Which & is 24 percent of the people. & \\
\hline$R 8>T 9$ & $\mathbf{R 9}$ & \\
\hline
\end{tabular}

\begin{tabular}{|c|c|c|}
\hline Related to social assistance, & We & have started to provide social aid yesterday. \\
\hline T10 & R10 \\
\hline
\end{tabular}




\begin{tabular}{|c|c|}
\hline We & $\begin{array}{r}\text { have launched the distribution of staple food to Greater Jakarta } \\
\text { and the Pre-employment Card program }\end{array}$ \\
\hline T10 > T11 & R11 \\
\hline
\end{tabular}

\begin{tabular}{|c|c|}
\hline Direct cash aid & will be also carried out by this week. \\
\hline R10 $>$ T12 & $\mathbf{R 1 2}$ \\
\hline
\end{tabular}

\begin{tabular}{|c|c|c|}
\hline For that reason, & I & would like to announce a decision. \\
\hline T3 $>$ T13 & $\mathbf{R 1 3}$ \\
\hline
\end{tabular}

\begin{tabular}{|c|c|c|c|c|}
\hline After & $\begin{array}{c}\text { prohibiting State Civil Apparatus (ASN), } \\
\text { Indonesian Military (TNI) personnel, the } \\
\text { National Police (Polri) personnel, and the } \\
\text { state-owned enterprises (BUMN) } \\
\text { employees from returning to their } \\
\text { hometowns, }\end{array}$ & at today's meeting I & $\begin{array}{c}\text { would like } \\
\text { to say }\end{array}$ \\
\hline \multicolumn{2}{|c|}{ T4 } & R14 \\
\hline That & We & will also ban a massive exodus & \\
\hline \multicolumn{2}{|c|}{ R15 } \\
\hline
\end{tabular}

\begin{tabular}{|c|c|c|}
\hline Therefore, & I & ask for any preparations regarding the issue. \\
\hline R15 > T16 & R16 \\
\hline
\end{tabular}

\begin{tabular}{|c|c|}
\hline And that & concludes my remarks. \\
\hline R15 > T17 & $\mathbf{R 1 7}$ \\
\hline
\end{tabular}

The more simple way to see the thematic progression of the target language (TL) speech text is presented in the following chart.

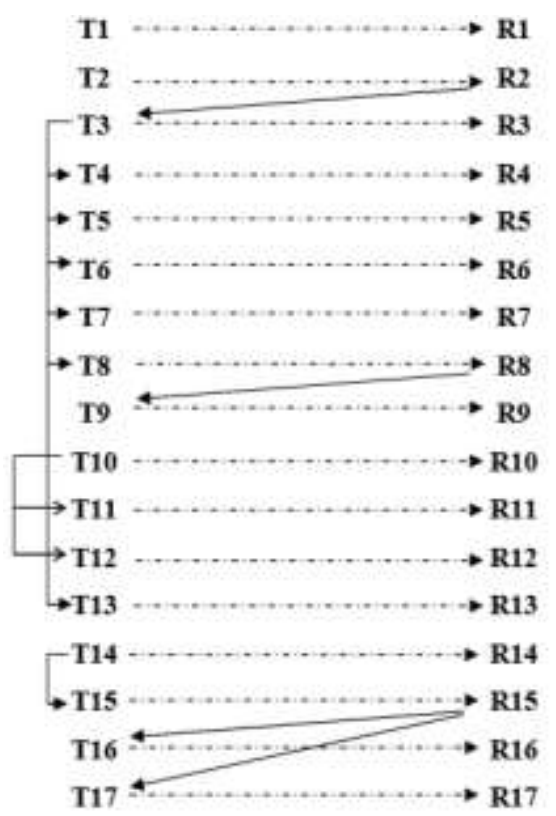

Fig 2. Thematic progression of TL speech text 
Based on the thematic progression analysis above, the English ( $T L$ ) speech text or the translation version also employs all types of thematic progressions comprising and split rheme thematic progression, simple linear thematic progression, theme derived thematic progression, and constant thematic progression.

The detail of the usage frequency is described in table 4 below.

Table 4.

Usage Frequency of Thematic Progression in TL Speech Text

\begin{tabular}{llllll}
\hline No & Type of TP & Freq. & $\%$ & Position & Rank \\
\hline 1. & $\begin{array}{l}\text { Simple linear thematic } \\
\text { progression }\end{array}$ & 3 & $23 \%$ & $\mathrm{R} 2>\mathrm{T} 3, \mathrm{R} 8>\mathrm{T} 9, \mathrm{R} 10>\mathrm{T} 12$ & 2 \\
2. & $\begin{array}{l}\text { Constant thematic progression } \\
\text { (2) }\end{array}$ & 2 & $15 \%$ & $\mathrm{~T} 14>\mathrm{T} 15$ & 3 \\
3. & $\begin{array}{l}\text { Theme derived thematic } \\
\text { progression }\end{array}$ & 6 & $47 \%$ & $\mathrm{~T} 3>\mathrm{T} 4, \mathrm{~T} 5, \mathrm{~T} 6, \mathrm{~T} 7, \mathrm{~T} 8, \mathrm{~T} 13$ & 1 \\
& $\begin{array}{l}\text { Split rheme thematic } \\
\text { progression }\end{array}$ & 2 & $15 \%$ & $\mathrm{R} 15>\mathrm{T} 16, \mathrm{~T} 17$ & 3 \\
\hline
\end{tabular}

The most frequent use of thematic progression in SL speech text is theme derived thematic progression as the main theme (T3) "based on the results of the research on the ground, the deepened research on the ground, as well as the results of a survey conducted by Ministry of Transportation," is used as the basis to develop subthemes in T4 (68 percent of people), T5 (while 24 percent), T6 (and 7 percent), T7 (It), and T13 (For that reason, I...).

This research aims to analyze the theme and rheme as well as the thematic progression that appear in both Indonesia (SL) and English (TL) speech texts. Then, based on the analysis, the findings have been presented in the previous chapter.

\section{Theme-rheme Analysis Discussion}

Comparing the existence of themes and rheme in both texts, the types of used themes are similar in frequency and dominant. The most frequently used theme that appears on the speech text is topical theme. As the theory mentions that topical theme is characterized by the existence of participant, circumstance or subject as the constituent. The function of topical theme is to emphasize the topic or subject that it is the primary goal of the speech which is in the current research is in speech text. The category of topical theme is included pronoun, adverbial, and nominal. In the speech text, the speaker often used it.

The unique difference on the use of topical themes in both speeches relies on the categories of the topical theme. In SL speech text, circumstantial of matter 
category such as in "dari hasil kajiankajian yang ada di lapangan, pendalaman yang ada di lapangan, kemudian juga dari hasil survei yang dilakukan oleh Kementerian Perhubungan;” ...(referring to amount of number) "yang tidak mudik;" ...(referring to amount of number) "yang tetap masih...;" ...(referring to amount of number) "yang sudah mudik; ...yang kedua; bansos; kartu prakerja; bantuan sosial (bansos) tunai; ... larangan mudik bagi ASN, TNI, Polri, dan pegawai BUMN sudah kita lakukan pada minggu yang lalu; mudik semuanya; persiapanpersiapan;" and ini dominate the use of topical theme. While, in the TL speech text, participant category such as in "me", "we", "I", and "it" become the most frequently used of topical theme.

The second frequently used theme is textual theme. In the SL speech text, among three categories in textual themes, there are only conjunctive adjunct and conjunction. The speaker used some words like jadi, kemudian, and oleh sebab itu to make good connection of ideas between clauses and sentences. Similarly, the TL speech text also ranks textual theme as the second with percentage is $33 \%$ that is $7 \%$ higher than in SL speech text. Uniquely, TL speech text employs continuity category for the word 'let' while there is not any in SL speech text. The conjunctive adjunct and conjunction that are found in the text are so, therefore, and that, after, for, while, which, and that. Most of the conjunctions in the text are placed in the beginning of the clause and the conjunctive adjuncts are situated in the clause.
The least used theme is interpersonal theme. This kind of theme indicates the position of the speaker or the writer toward the text or to maintain relationship between speaker or writer with the audience or reader. ${ }^{29}$ Unfortunately, there is not any of this theme in TL speech text while there are two in SL speech text. The examples of them are "selamat pagi, salam sejahtera" and "saya rasa". Those two examples show that the speaker applies mood adjuncts as way to maintain connection with the audience. It is in line with Fang's research stating that mood adjuncts can add meaning to the mood element, ${ }^{30}$ therefore the use of mood adjuncts are vital in keeping the mood of the speakers or audiences.

The finding on the theme-rheme in both $\mathrm{TL}$ and $\mathrm{SL}$ speech texts shows similar ideas as the research done by Octaviani entitled "theme-rheme and thematic progression in Obama's speech and its translation". ${ }^{31}$ She states that the topical theme is the most dominant theme in Obama's speech. Then, it is followed by the textual and interpersonal themes. The same results are also depicted in the research entitled "the analysis of theme-

\footnotetext{
29 Paltridge, Discourse Analysis: An Introduction, 147.

${ }^{30}$ Yanqing Fang, "The Realization of Mood through Lexical Choices in English Public Service Advertising Texts," vol. 238 (8th International Conference on Social science and Education Research (SSER 2018), Xi'an, China: Atlantis Press, 2018), 226-223, https://doi.org/10.2991/sser-18.2018.47.

31 Mufti Rizki Oktaviani, "Theme-Rheme and Thematic Progression in Obama's Speech and Its Translation," Passage 1, no. 3 (2013): 43-56.
} 
rheme organization on Jokowi widodo's speech" by Sinulingga \& Hasibuan. ${ }^{32}$ They stated that $87 \%$ of clauses that are in the speech are topical theme. The textual theme sit as the second with $11 \%$ application, and the interpersonal theme is only $2 \%$ in the speech text. The research strengthens this research's findings that topical theme always becomes the most frequently used in the speech text due to the importance of delivering the goal or topic to the audience.

\section{Thematic Progression Analysis Discussion}

Thematic progression in a text will influence the understanding and interpretation of the audience or the reader as it brings the cohesion or the unity of the information in the text or speech. The result of the thematic progression analysis found that both of the SL and TL speech texts have employed all types of thematic progression as proposed by Dane. It means that both of them have used cohesive devices to link ideas in the speech text. Both speech texts also employ theme-derived thematic progression type as the most dominant in texts which the main theme becomes the basis for developing some related theme. ${ }^{33}$ This result does not show the

\footnotetext{
${ }^{32}$ Amsaldi Wahyu Kristian Sinulingga and Asnita Hasibuan, "The Analysis of Theme-Rheme Organization on Joko Widodo's Speech," Pendidikan Bahasa Indonesia dan Sastra (PENDISTRA) 2, no. 2 (2019): 65-70, https://doi.org/10.1234/pbis.v2i2.593.

${ }^{33}$ Rusdi Noor Rosa, "Thematic Progression as a Model Used to Keep Cohesion in Writing an
}

same position as research on thematic progression in Obama's speech by Octaviani. ${ }^{34}$ Though Octaviani discusses similar presidential speech, her result shows that theme reiteration or simple linear thematic progression is the most dominant in Obama's speech.

\section{Conclusion}

The current research revealed the types of themes and thematic progression in Joko Widodo's speech to reduce the spreading of the COVID-19 pandemic. The topical theme becomes the most frequent type of theme, emphasizing the importance of the topic in both Bahasa Indonesia as source language (SL) and English as target language (TL) speech texts. Furthermore, the $S L$ and $T L$ speech texts have employed all types of thematic progression that imply the cohesion of the topic has been well developed.

\section{References}

Daneš, Frantisek. "Functional Sentence Perspective and the Organization of the Text." In On Subject and Theme, by Frantisek Daneš, 108-24. Amsterdam: John Benjamins Publishing, 1974.

Downing, Angela. "Thematic Progression as A Functional Resource in Analyzing the Text." In Os Estudios Ingleses no Contexto das Novas Tendencias, by M.T. Caneda and J. Pérez, 23-42. Vigo: Universidade de Vigo, 2001.

Exposition Text," Jurnal Bahasa dan Seni 8, no. 2 (2007): 94-103.

34 Oktaviani, "Theme-Rheme and Thematic Progression in Obama's Speech and Its Translation," 1. 
Eggins, Suzanne. An Introduction to Systemic Functional Linguistics. 2nd ed. New York: Continuum International Publishing Group, 2004.

Fang, Yanqing. "The Realization of Mood through Lexical Choices in English Public Service Advertising Texts," 238:226-223. Xi'an, China: Atlantis Press, 2018. https://doi.org/10.2991/sser18.2018.47.

Gerot, Linda, and Peter Wignell. Making Sense of Functional Grammar. Cammeray: Antipodean Educational Enterprises, 1995.

Giroux, Henry A. Pedagogy and the Politics of Hope: Theory, Culture, and Schooling. Oxford: Westview Press, 1997.

Halliday, M. A. K., and Christian M.I.M. Matthiessen. Introduction to Functional Grammar. 4th ed. London: Routledge, 2014.

Hawes, Thomas. "Thematic Progression in the Writing of Students and Professionals." Ampersand 2 (2015): 93-100. https://doi.org/10.1016/j.amper.2015 .06.002.

Humas Sekretariat Kabinet Republik Indonesia. "Rapat Terbatas melalui Video Conference Mengenai Lanjutan Pembahasan Antisipasi Mudik, 21 April 2020, di Istana Merdeka, Provinsi DKI Jakarta," April 21, 2020. https://setkab.go.id/rapat-terbatasmelalui-video-conference-mengenailanjutan-pembahasan-antisipasimudik-21-april-2020-di-istanamerdeka-provinsi-dki-jakarta/.

Indonesia, C. N. N. "Update Corona 21 April: 7.135 Positif, 616 Meninggal." nasional. Accessed November 21, 2020.

https://www.cnnindonesia.com/nasio nal/20200421120855-20-

495594/update-corona-21-april-

7135-positif-616-meninggal.
Liu, Quing-Feng. "Thematic Selection and Progression in EFL Writing." USChina Foreign Lang. 7, no. 7 (2009): 25-29.

Liu, S. "Thematic Progression: Analysis and Interpretation." US-China Foreign Lang. 2, no. 12 (2004): 6871.

Office of Assistant to Deputy Cabinet Secretary for State Documents \& Translation. "Introductory Remarks of President of the Republic of Indonesia During the Limited Cabinet Meeting Through Video Conference on the Additional Discussion for the Anticipation of Anual Exodus." Sekretariat Kabinet Republik Indonesia, April 22, 2020. https://setkab.go.id/en/introductoryremarks-of-president-of-therepublic-of-indonesia-during-thelimited-cabinet-meeting-throughvideo-conference-on-the-additionaldiscussion-for-the-anticipation-ofanual-exodus-tuesday/.

Oktaviani, Mufti Rizki. "Theme-Rheme and Thematic Progression in Obama's Speech and Its Translation." Passage 1, no. 3 (2013): 43-56.

Paltridge, Brian. Discourse Analysis: An Introduction. New York: Continuum, 2006.

Ping, Alvin Leong. "Developing the Message: Thematic Progression and Student Writing." The Journal of Asia TEFL 4, no. 3 (2007): 93-127.

Ridha, Nada Salih Abdul. "Theme and Rheme: Types and Problems in EFL University Students' Written Texts." Journal of Basrah Researches (Humanities Series) 39, no. 1 (2014): 94-114.

Rosa, Rusdi Noor. "Thematic Progression as a Model Used to Keep Cohesion in Writing an Exposition Text." Jurnal Bahasa dan Seni 8, no. 2 (2007): 94-103. 
Sinulingga, Amsaldi Wahyu Kristian, and Asnita Hasibuan. "The Analysis of Theme-Rheme Organization on Joko Widodo's Speech." Pendidikan Bahasa Indonesia dan Sastra (PENDISTRA) 2, no. 2 (2019): 6570.

https://doi.org/10.1234/pbis.v2i2.593.

Wang, Lixia. "Theme and Rheme in the Thematic Organization of Text: Implications for Teaching Academic Writing." The Asian EFL Journal Quarterly 9, no. 1 (2007): 164-76. http://www.asian-efl-

journal.com/March_2007_EBook.pdf.

Yang, Xueqian. "Thematic Progression Analysis in Teaching Explanation Writing." English Language Teaching 1, no. 1 (2008): 29-33. https://doi.org/10.5539/elt.v1n1p29.

Yunita, Sri. "Theme and Thematic Progression in Students' Recount Texts." Indonesian Journal of Applied Linguistics 7, no. 3 (2018): 524.

https://doi.org/10.17509/ijal.v7i3.979 7.

Zhang, Jianyun. "Necessity of Grammar Teaching." International Education Studies 2, no. 2 (2009): 184-97. https://doi.org/10.5539/ies.v2n2p184. 